\title{
Effects of Vitamin E Supplementation on Serum Hormones and Gene Expression of Anti-season Breeding Xingguo Grey Geese (Anser cygnoides)
}

http://dx.doi.org/10.1590/1806-9061-2018-0892

\section{-Author(s)}



Farm Animal Genetic Resources Exploration and Innovation Key Laboratory of Sichuan Province, Sichuan Agricultural University, Chengdu Campus, Chengdu, 611130, Sichuan, China.

Sichuan Animal Science Academy, Chengdu, 610066, Sichuan, China

II Institute of Animal Husbandry and Veterinary Sciences, Jiangxi Academy of Agricultural Science, Nanchang, 330200, Jiangxi, China.

These authors contributed equally to this work and shall share the first author.

'These authors share the corresponding author.

\section{mail Address}

Corresponding author e-mail address Prof. Yi-Ping Liu

Farm Animal Genetic Resources Exploration and Innovation Key Laboratory of Sichuan Province, Sichuan Agricultural University, 211 Huiming Road, Wenjiang, Chengdu, Sichuan Province, China.

Email: liuyp578@163.com

\section{- Keywords}

Vitamin E, Reproductive hormones, Ovary, Follicle, Dicer.

\section{ABSTRACT}

The objective of this study was to analyse the impact of dietary vitamin E supplementation on laying performance, serum reproductive hormones concentration and gene expression in ovary and follicles of anti-season breeding goose. A total of 210 anti-season breeding geese were divided into seven treatments with six replications. Each group was supplied with diets containing different vitamin $\mathrm{E}$ ( $\mathrm{DL}$ - $\alpha$-tocopherol acetate) contents $(0,10,20,40,80,160,320 \mathrm{mg} / \mathrm{kg})$. We observed that the egg production and laying rate improved significantly at doses of 10 and $80 \mathrm{mg} / \mathrm{kg}$, while the highest egg weight appeared in the $320 \mathrm{mg} / \mathrm{kg}$ group. Meantime, $80 \mathrm{mg} / \mathrm{kg}$ of vitamin E supplementation significantly improved the concentration of follicle-stimulating hormone $(\mathrm{FSH})$, luteinizing hormone $(\mathrm{LH})$ and estradiol $(\mathrm{E} 2)$ in serum $(p<0.05)$. Dietary vitamin E supplementation significantly enhanced mRNA expression of $F S H R, L H R$ and ESR 1 at a dose of $80 \mathrm{mg} / \mathrm{kg}$, while $P R L R$ increased at doses of 10 and $20 \mathrm{mg} / \mathrm{kg}(p<0.05)$. It was found that the mRNA expression of Dicer increased at doses of 40 and $80 \mathrm{mg} / \mathrm{kg}$ of vitamin E supplementation in the ovary, SWF, LWF and SYF, respectively. Thence, Dietary vitamin E supplementation could improve egg laying performance, plasma reproductive hormones and the mRNA expression of reproductive hormone receptor genes in ovary, as well as the mRNA expression of Dicer in ovary, SWF, LWF and SYF. It was supposed that $80 \mathrm{mg} / \mathrm{kg}$ of vitamin E supplementation in dietary was appropriate to improve the fertility of anti-season breeding Xingguo grey goose.

\section{INTRODUCTION}

The egg production of poultry is an essential economic problem in husbandry. Caused by the seasonal reproduction, the development of goose industry is sluggish compared with chicken in nowadays breeding industry. With respect to this issue, a valid method called "short illumination control technology and forced moulting method was applied to accomplish anti-season reproduction of goose. Xingguo Grey Goose is a popular indigenous breed distributed in Jiangxi Province. With a strong seasonal reproduction characteristic, the annual egg production of Xingguo Grey Goose is approximately 3040 eggs per goose. It has been reported that Xie and colleagues used the short illumination control technology and forced moulting method to accomplish the anti-season breeding of Xingguo Grey Goose (Xie et al., 2011). In consideration of the broody stages of Xingguo Grey Goose from May to August, herein, we adopted this method to regulate the reproductive cycle of Xingguo Grey Goose for anti-season breeding. Ceasing egg-laying is usually observed in geese during the non-breeding period because of the decrease of follicles. After the nonbreeding period, the secretion of several reproductive hormones, such as FSH and LH are increased (Xie et al., 2011), which promotes follicles 
to increase and develop rapidly in the ovary. Hence, we detected the concentration of reproductive hormones after vitamin $\mathrm{E}$ treatment in this study.

Vitamin E consists of four tocopherols and four tocotrienols, of which $\alpha$-tocopherol is the main biologically active form. Since it was discovered in the 1920s, vitamin E has demonstrated to own numerous functions, such as anti-oxidation, cellular immune regulation and lipids transportation. In humans, adding vitamin E ( $\alpha$-tocopherol) to endothelial cells and fibroblasts cells in vitro could reduce the numbers of senescent cells and protect against $\mathrm{H}_{(2)} \mathrm{O}_{(2)}$-induced DNA damage and telomere shortening (Makpol et al., 2010). In pigs, vitamin $\mathrm{E}$ integrated with other elements could reduce percent peroxide hemolysis, serum cholesterol and fatty acid levels (Young et al., 1976). In ruminants, the supplementation of vitamin $\mathrm{E}$ was thought to affect the numbers of some immune cell types in the peripheral blood of suckling Japanese black calves (Otomaru et al., 2015). It was also suggested that the saturated fatty acid decreased and monounsaturated fatty acid increased when Aohan fine-wool sheep supplied with 200 IU vitamin E (Liu et al., 2013). As for poultry, the available evidence seems to point to the essential role of vitamin E in meat quality, growth performance, lipids metabolism, immunity and fertility. High levels of vitamin $E(150 \mathrm{mg} / \mathrm{kg})$ in the diets could improve the antioxidant function and lipids metabolism of Guangxi Sanhuang chicken (Liu et al., 2017). Biswas's findings claimed that moderate supplementation of dietary vitamin $E(100 \mathrm{mg} / \mathrm{kg})$ may improve physical and biochemical characteristics of semen in Indian reared KN cock (Biswas et al., 2009). However, the impact of vitamin $\mathrm{E}$ on goose reproduction is relatively less reported.

Dicer, an RNase III endonuclease, is critical for small noncoding RNAs (micro RNAs and small interfering RNAs) synthesis, as well as regulating mRNA expression in transcriptional and post-transcriptional modifications via binding to target mRNA and leading to subsequent mRNA degradation (Song \& Rossi, 2017). Currently, Dicer was also reported to involve in follicular development, ovulation, luteinization and reproductive hormone synthesis (Kurzynska-Kokorniak et al., 2015). Otherwise, Dicer could also affect the development and function of corpus luteum via corpus luteum angiogenesis (Otsuka et al., 2008). Although Dicer may play a critical role in fertility, especially in gonadotropin homeostasis, fewer reports related to the effect of vitamin E supplementation on the expression of Dicer in ovary and follicles was found.
Generally, we employed the anti-season breeding Xingguo Grey Goose to investigate the effects of vitamin E supplementation on plasma reproductive hormones concentration and the expression of reproductive hormones genes and Dicer in ovary and follicle. Further to reveal the effect of vitamin $E$ supplementation on the fertility of goose at physiological level.

\section{MATERIALS AND METHODS}

All experimental protocols involving animals in the present study were approved by the Committee on the Care and Use of Laboratory Animals of the State-Level Animal Experimental Teaching Demonstration Centre of Sichuan Agricultural University and Jiangxi Academy of Agriculture Sciences. All methods involved in this study were conducted according to the Regulations of the Administration of Affairs Concerning Experimental Animals.

\section{Animal treatment}

All experiment animals were raised in Xingguo Grey Goose Research Base (annual temperature average is $\left.18.9^{\circ} \mathrm{C}, 115^{\circ} 35^{\prime} \mathrm{E}, 26^{\circ} 33^{\prime} \mathrm{N}\right) .210$ healthy laying geese aged 45 weeks (in the middle of egg production period) were selected and treated with forced moulting method and short illumination(13L: 11D) established by Xie and colleagues (Xie, Liu, Yan-Ping, Zhou, Xie, Wei, Kang, Hua-Yuan, Huang, Zeng, 2011) to regulate the reproductive cycle of Xingguo grey goose. After a recovery period of about four weeks, 210 geese were randomly divided into seven groups ( 6 replicates, 5 observations). All geese were supplied with a commercial ration (Table 1) containing increasing levels of vitamin E supplementation $(0,10,20,40,80,160$,

Table 1 - Composition and nutrient levels of experimental diets (air-dry basis).

\begin{tabular}{lc}
\hline Ingredients & Percentage (\%) \\
\hline Corn & 40 \\
Paddy & 40 \\
Soybean meal & 16.04 \\
stone dust & 1.44 \\
Calcium phosphate dibasic & 1.52 \\
Premix ${ }^{1)}$ & 1 \\
Constituents & \\
ME(MJ/Kg) & 11.39 \\
Crude protein(CP) & 14.11 \\
Ca & 0.94 \\
P available & 0.62 \\
\hline
\end{tabular}

1) Contained the following per $\mathrm{kg}$ of premix: Cu (as copper sulfate) $10 \mathrm{mg}$, Fe (as ferrous sulfate) $90 \mathrm{mg}$, Se (as sodium selenite) $0.2 \mathrm{mg}$, Zn (as zinc sulfate) $80 \mathrm{mg}$, VA 9000 IU, VD 2000 IU, VE 20 IU, VK 2.50 mg, VB, 2.50 mg, VB 4.50 mg, VB 4 mg, pantothenic acid $10 \mathrm{mg}$, choline $800 \mathrm{mg}$, nicotinic acid $50 \mathrm{mg}$ and folic acid $1 \mathrm{mg}$. 
$320 \mathrm{mg} / \mathrm{kg}$ ). Seven treatments were kept in a lightshelter room and exposed to an artificial short lighting program (11L:13D) with ad libitum access to feed and water. This treatment lasted for 12 weeks until all geese went into egg-laying period again. To calculate the laying rate of each group, the egg production and egg weight were recorded for three weeks in each group.

\section{Blood sample collection and serum hor- mone concentration analysis}

We collected six laying geese from each treatment. Each bird was sampled three times, with a $48 \mathrm{~h}$ sampling interval, which is considered as the theoretical oviposition cycle. All the blood samples were collected from the wing vein using heparinized syringes. To separate the serum, we centrifuged the blood samples at $3000 \mathrm{xg}$ for $10 \mathrm{~min}$ at $4^{\circ} \mathrm{C}$ and stored at $-20^{\circ} \mathrm{C}$ until analysis. The ELISA kits (Kenuodi, Fujian, China) with the intra-assay and inter-assay were used to evaluate the concentration of follicle-stimulating hormone $(\mathrm{FSH})$, luteinizing hormone $(\mathrm{LH})$, prolactin (PRL) and estradiol (E2) in serum. The coefficient of variation was less than $15 \%$ precision. A total of 42 samples were measured in triplicates for each sample. The enzymelabelled instrument (Thermo Fisher, Varioskan ${ }^{\mathrm{TM}}$ LUX, Germany) was used to measure absorbance at $450 \mathrm{~nm}$.

\section{Ovarian tissues collection, RNA extraction, CDNA synthesis, and real-time PCR analysis}

A total of 42 fowls (6 fowls for each treatment) were selected randomly and slaughtered for ovary and follicle tissues collection. The ovarian tissues were separated, small white follicles (SWF, $1 \mathrm{~mm} \leq \mathrm{d} \leq 3 \mathrm{~mm}$ ), large white follicles (LWF, $6 \mathrm{~mm} \leq \mathrm{d} \leq 10 \mathrm{~mm}$ ) and small yellow follicles (SYF, $10 \mathrm{~mm} \leq \mathrm{d} \leq 20 \mathrm{~mm}$ ), were frozen in liquid nitrogen immediately, and stored at $-80^{\circ} \mathrm{C}$ until analysis. Total RNAs were extracted using the Trizol
RNA extraction reagent (Invitrogen Corp., CA, USA) and reverse transcribed to CDNA using PrimeScript ${ }^{\mathrm{TM}}$ RT reagent Kit (Perfect Real-Time, Takara, Dalian, China) in accordance with the manufacturer's instruction. Realtime quantitative PCR analysis of follicle-stimulating hormone receptor (FSHR), luteinizing hormone receptor $(L H R)$, prolactin receptor $(P R L R)$, estradiol receptor 1 (ESR1) and Dicer mRNA were performed with $\beta$-actin as the internal control standard. The primers of target genes were listed in Table 2. Real-time quantitative PCR was conducted on ABI 7500 Fluorescent Quantitative PCR system (Applied Biosystems, Bedford, MA, USA) using a $20 \mu \mathrm{L}$ reaction volume with SYBR Green I Master Mix (Toyobo, Osaka, Japan). The real-time quantitative PCR conditions were: $95^{\circ} \mathrm{C}$ pre-denaturation for 5 minutes, 40 cycles of $95^{\circ} \mathrm{C}$ for $15 \mathrm{~s}, 60^{\circ} \mathrm{C}$ for $35 \mathrm{~s}$, and melting curves were obtained at $60^{\circ} \mathrm{C}$ for $60 \mathrm{~s}$ to $95^{\circ} \mathrm{C}$ for $15 \mathrm{~s}$. All assays were performed in triplicate. The $2^{-\Delta \Delta \mathrm{Ct}}\left(\Delta \mathrm{Ct}=\mathrm{Ct}_{\text {gene }}-\mathrm{Ct}_{\beta \text {-actin' }}\right.$ Ct: cycle threshold values) was represented as the relative quantification of gene amplification.

\section{Statistical analysis}

All statistics were disposed in EXCEL 2010 and then analysed by one-way ANOVA of SAS Software Version 9.2 (SAS Institute Inc. Cary, NC. USA). Variance analysis was performed to evaluate the differences, and Duncan post hoc test was employed to determine the effects of treatments at $1 \%$ or $5 \%$ level of significance $(p<0.01$, or $p<0.05)$. All results were presented as mean $\pm S D$ (standard deviation of the mean).

\section{RESULTS}

\section{Egg-laying performance}

The effect of different levels of dietary vitamin E supplementation on egg laying performance was

Table 2 - Primers used in real-time quantitative PCR of genes in geese samples ${ }^{1)}$

\begin{tabular}{|c|c|c|c|c|}
\hline Gene name & Accession number & Prime sequences $\left(5^{\prime} \rightarrow 3^{\prime}\right)$ & Annealing temperature $\left({ }^{\circ} \mathrm{C}\right)$ & PCR product (bp) \\
\hline \multirow[t]{2}{*}{ Dicer } & XM_013181712.1 & Forward primer: TGCCCACAGAATACCGTTCC & 60.04 & 193 \\
\hline & & Reverse primer: GGTTCAGTTTCGGTTTCGCC & 60.04 & \\
\hline \multirow[t]{2}{*}{ ESR1 } & XM_013178336.1 & Forward primer: TCCAGTGTACGGCTCTACCA & 59.96 & 120 \\
\hline & & Reverse primer: TGCAAGAACACCACAGGGTT & 60.03 & \\
\hline \multirow[t]{2}{*}{ LHR } & XM_013192443.1 & Forward primer: TTACAAGCTCACGGTTCCCC & 59.96 & 255 \\
\hline & & Reverse primer: TGCATGGCGTAGGTGATTGT & 60.04 & \\
\hline \multirow[t]{2}{*}{ FSHR } & XM_013192472.1 & Forward primer: ATGTTTGCTTTCACGGTGGC & 59.97 & 275 \\
\hline & & Reverse primer: GCCATGCAGAGGAAGTCTGT & 60.04 & \\
\hline \multirow[t]{2}{*}{ PRLR } & XM_013181699.1 & Forward primer: AAGGAGCCGGGAAACTCAG & 59.96 & 198 \\
\hline & & Reverse primer: CCACCAAAACTGGGGCAATG & 59.96 & \\
\hline$\beta$-actin & NW_013185670.1 & $\begin{array}{l}\text { Forward primer: AGAGGTGGGAACCACACTTG } \\
\text { Reverse primer: TCCCCTTGTCAAAGCACTCC }\end{array}$ & $\begin{array}{l}59.53 \\
59.89\end{array}$ & 162 \\
\hline
\end{tabular}

1) ESR1: estradiol receptor 1; LHR: luteinizing hormone receptor; FSHR: follicle-stimulating hormone receptor; PRLR: prolactin receptor. 
presented in Table 3. Different dietary levels of vitamin E supplementation had significant effect on the egg production, laying rate and average egg weight of Xingguo geese. The egg production and laying rate at doses of 10 and $80 \mathrm{mg} / \mathrm{kg}$ vitamin E supplementation were extremely significantly higher than the control group $(p<0.01)$ but decreased at doses of 20 and $160 \mathrm{mg} / \mathrm{kg}$ vitamin $\mathrm{E}$ addition $(p<0.05)$. The highest average egg weight was observed in $320 \mathrm{mg} / \mathrm{kg}$ group, which increased significantly compared with the control one $(p<0.05)$.

Table 3 - Egg-laying performance of the geese ${ }^{1)}$

\begin{tabular}{|c|c|c|c|}
\hline $\mathrm{VE}(\mathrm{mg} / \mathrm{kg})$ & Egg production & Laying rate & Average egg weight \\
\hline 0 & $20.67 \pm 3.56$ & $0.20 \pm 0.034$ & $171.02 \pm 3.09$ \\
\hline 10 & $26.17 \pm 2.48^{* *}$ & $0.25 \pm 0.023^{* *}$ & $170.81 \pm 2.02$ \\
\hline 20 & $17.33 \pm 1.21^{*}$ & $0.17 \pm 0.012^{*}$ & $169.38 \pm 4.23$ \\
\hline 40 & $22.00 \pm 2.19$ & $0.21 \pm 0.021$ & $168.91 \pm 2.43$ \\
\hline 80 & $27.33 \pm 1.63^{* *}$ & $0.26 \pm 0.016^{* *}$ & $165.73 \pm 1.79^{*}$ \\
\hline 160 & $17.83 \pm 0.41^{*}$ & $0.17 \pm 0.003^{*}$ & $168.71 \pm 5.65$ \\
\hline 320 & $18.83 \pm 2.56$ & $0.18 \pm 0.024$ & $176.16 \pm 3.51^{*}$ \\
\hline
\end{tabular}


difference $(p<0.01)$.

\section{Concentration of reproductive hormones in serum}

The data presented in Table 4 showed that different levels of vitamin E supplementation had effects on serum reproductive hormones in anti-season breeding geese. The FSH concentration was extremely significantly higher at doses of 40,80 and $160 \mathrm{mg} /$ $\mathrm{kg}$ than in the control group $(p<0.05)$ and showed a peak at the dose of $80 \mathrm{mg} / \mathrm{kg}$. The results (Table 4, Figure $1 \mathrm{~A}$ ) suggest that FSH concentration at the dose of $80 \mathrm{mg} / \mathrm{kg}$ was approximately 15 times higher than

A



C



in the control from $0.38 \pm 0.29$ to $5.87 \pm 1.49 \mathrm{mlU} / \mathrm{ml}$. Similar to the trend of FSH, the concentration of E2 also increased at doses of 20,40,80 and $160 \mathrm{mg} / \mathrm{kg}$ compared with the control group. The concentration of LH only increased significantly at the dose of $80 \mathrm{mg} / \mathrm{kg}$ $(p<0.05)$. Whereas PRL concentration (Table 4, Figure 1B) increased from $0 \mathrm{mg} / \mathrm{kg}(5.72 \pm 0.41)$ to $20 \mathrm{mg} / \mathrm{kg}$ (15.41 \pm 3.19$)$, and a peak was showed at $20 \mathrm{mg} / \mathrm{kg}$. Then PRL concentration decreased from $20 \mathrm{mg} / \mathrm{kg}$ to $40 \mathrm{mg} / \mathrm{kg}$, but when the dose above $40 \mathrm{mg} / \mathrm{kg}$, the concentration of PRL increased again.



D



Figure 1 - Serum concentrations of FSH, PRL, E2, LH during the oviposition or ovulation cycle. Vertical bars represent standard deviation of the mean. Means not marked by a common letter are significantly different $(p<0.05)$. 
Table 4 - Serum hormone concentration of the geese ${ }^{1)}$

\begin{tabular}{lccccccc}
\hline variable & $0 \mathrm{mg} / \mathrm{kg}$ & $10 \mathrm{mg} / \mathrm{kg}$ & $20 \mathrm{mg} / \mathrm{kg}$ & $40 \mathrm{mg} / \mathrm{kg}$ & $80 \mathrm{mg} / \mathrm{kg}$ & $160 \mathrm{mg} / \mathrm{kg}$ & $320 \mathrm{mg} / \mathrm{kg}$ \\
\hline $\mathrm{FSH}(\mathrm{mlU} / \mathrm{ml})$ & $0.38 \pm 0.29$ & $1.84 \pm 0.96^{*}$ & $0.99 \pm 0.23$ & $3.47 \pm 1.640^{* *}$ & $5.87 \pm 1.49^{* *}$ & $4.19 \pm 0.58^{* *}$ & $0.39 \pm 0.16$ \\
$\mathrm{PRL}(\mathrm{mlU} / \mathrm{L})$ & $5.72 \pm 0.41$ & $9.29 \pm 2.71 \mathrm{~B}^{* *}$ & $15.41 \pm 3.19^{* *}$ & $6.01 \pm 0.62$ & $7.80 \pm 0.68$ & $8.99 \pm 1.30^{* *}$ & $10.92 \pm 2.03^{* *}$ \\
$\mathrm{E} 2(\mathrm{pg} / \mathrm{ml})$ & $295.83 \pm 23.77$ & $318.75 \pm 57.37$ & $449.77 \pm 84.39^{*}$ & $468.29 \pm 40.51^{*}$ & $620.37 \pm 181.35^{* *}$ & $443.06 \pm 151.04^{*}$ & $326.85 \pm 29.19$ \\
$\mathrm{LH}(\mathrm{g} / \mathrm{ml})$ & $102.99 \pm 12.27$ & $88.85 \pm 7.41$ & $126.16 \pm 15.55$ & $127.29 \pm 37.52$ & $175.48 \pm 43.59^{* *}$ & $134.41 \pm 36.21$ & $110.53 \pm 17.98$ \\
\hline
\end{tabular}

${ }^{1)}$ Serum hormone concentration was presented as mean $\pm S D$ (standard deviation of the mean)( $\left.n=6\right)$. FSH, follicle-stimulating hormone. PRL, prolactin. E2, estrogen. $L H$, luteinizing hormone. "*" or "**" on the row denotes significant difference $(p<0.05)$ or extremely significant difference $(p<0.01)$.

\section{Reproductive hormone gene expression in the ovary}

The relative mRNA expression of FSHR, PRLR, ESR1 and $L H R$ in the ovary affected by dietary vitamin $E$ supplementation is shown in Figure 2. Compared with the control one, the relative mRNA expression of ESR1, FSHR and LHR significantly increased by dietary vitamin E supplementation at the dose of 40 or 80 $\mathrm{mg} / \mathrm{kg}(p<0.05)$. The result showed that there was no significant difference of ESR1and $L H R$ relative mRNA expression was observed between 40 and $80 \mathrm{mg} / \mathrm{kg}$. Conversely, $P R L R$ relative $m R N A$ expression significantly increased at doses of 10 and $20 \mathrm{mg} / \mathrm{kg}(p<0.05)$. Dietary vitamin E supplementation at 40 and $80 \mathrm{mg} / \mathrm{kg}$ had no significant impact on PRLR mRNA expression in the ovary, which was in contrast to the results of FSHR and ESR1. Among the four genes, FSHR showed

FSHR



ESR1



higher relative mRNA expression in ovary compared with the others, and the relative mRNA expression of $P R L R$ in the ovary was the lowest.

\section{Dicer expression in ovary, SWF, LWF, SYF}

As a transcriptome regulator, Dicer was supposed to participate in follicular growth and development. The effects of dietary vitamin E supplementation on Dicer relative mRNA expression in the ovary, small white follicle (SWF), large white follicle (LWF) and small yellow follicle (SYF) are presented in Figure 3. In the ovary, compared with the control group, the relative mRNA expression of Dicer significantly increased at the dose of $40 \mathrm{mg} / \mathrm{kg}$ and decreased at $320 \mathrm{mg} / \mathrm{kg}(p<0.05)$. In SWF and LWF, differing from other treatments, the relative mRNA expression of Dicer significantly increased at $80 \mathrm{mg} / \mathrm{kg}$ in contrast with the control group $(p<0.05)$. In SYF, the relative mRNA expression

PRLR

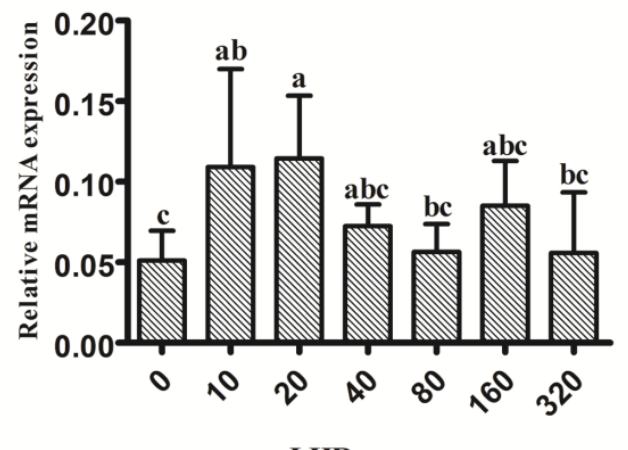

LHR



Figure 2 - The mRNA expression level of FSHR, PRLR, ESR1, LHR relative to $\beta$-actin in ovary of anti-season breeding Xingguo grey goose. Vertical bars represent standard deviation of the mean. Means not marked by a common letter are significantly different $(p<0.05)$. 
Ovary



LWF



SWF



SYF



Figure 3 - The mRNA expression level of Dicer relative to $\beta$-actin in ovary, SWF, LWF, SYF of anti-season breeding Xingguo grey goose. Vertical bars represent standard deviation of the mean. Means not marked by a common letter are significantly different $(p<0.05)$

of Dicer presented a tendency to decrease when the dose of vitamin $\mathrm{E}$ supplementation increased from 0 $\mathrm{mg} / \mathrm{kg}$ to $40 \mathrm{mg} / \mathrm{kg}$. The dose of $40 \mathrm{mg} / \mathrm{kg}$ vitamin $E$ supplementation significantly suppressed the relative mRNA expression of Dicer compared with the control group $(p<0.05)$. Otherwise, among the four tissues, the relative mRNA expression of Dicer was observed to express less in LWF and higher in SYF without vitamin E supplementation.

\section{DISCUSSION}

Vitamin $E$, the most abundant radical-scavenging antioxidant in vivo, is thought to affect the reproduction in humans and animals. It was described as that 30 and $60 \mathrm{mg} / \mathrm{kg}$ doses of dietary vitamin $\mathrm{E}$ had a significant impact on egg production rates and embryonic viability (Abedi et al., 2017). Biswas et al., reported that hens supplemented with $150 \mathrm{IU} / \mathrm{kg}$ VE significantly improved egg production and fertility (Biswas et al., 2010). Nevertheless, according to Hooda et al., 75, 150, 225 or $300 \mathrm{IU} / \mathrm{kg}$ vitamin E addition had no effect on the fertility and hatchability of Japanese quails (Hooda et al., 2007). Currently, supplementation of 10 and $80 \mathrm{mg} / \mathrm{kg}$ of vitamin $\mathrm{E}$ had an exceeding significant impact on the egg production and laying rate. However, when the geese were supplied with 20 and $160 \mathrm{mg} / \mathrm{kg}$ of vitamin $\mathrm{E}$, the egg production and laying rate were lower than the zero control. This result was not completely consistent with the variation of serum FSH and LH content (Figure 1), which was said to regulate the follicle development and ovulation. This can be interpreted as that the formation of eggs was a complex biological process, which was not only regulated by gonadal hormone levels. Although the egg production and laying rate increased at a dose of $80 \mathrm{mg} / \mathrm{kg}$ of vitamin $\mathrm{E}$ addition, the egg weight was the lowest. While the egg weight in $320 \mathrm{mg} / \mathrm{kg}$ group was terrific in spite of the egg production being lower than that in the $80 \mathrm{mg} / \mathrm{kg}$ group, confirming the results of previous studies that egg production was found to be negatively correlated with egg weight (Singh et al., 2000, Veeramani et al., 2012, Tongsiri et al., 2015).

Vitamin E influenced chicken's sexual function by regulating the secretion of gonadotropins from the anterior pituitary. The researches have shown that supplementation of dietary vitamins $\mathrm{E}$ enhanced the size and area of FSH and LH gonadotropic cells and modulated the function state of gonadotropic cells (Mumford et al., 2015). Herein, the gonadotropins 
FSH concentration in serum were improved by dietary vitamin E complement at doses of $20-160 \mathrm{mg} / \mathrm{kg}$ in anti-season breeding Xingguo grey geese and LH was at the dose of $80 \mathrm{mg} / \mathrm{kg}$, indicating that apposite vitamin $\mathrm{E}$ addition may impact the synthesis and release of gonadotropin in anterior pituitary. FSH mainly regulated follicular development and selection. The literature on Hardy et al. proved that FSH was essential for pre-antral follicle growth and function in mice (Hardy et al., 2017). In poultry, FSH treatment increased the embryonic chicken ovarian germ cell number, granulosa cells number and reduced cell apoptosis in different stage of follicles(Lin et al., 2011). In this study, the increase of FSH and LH in geese may induce follicular development and ovulation which may result in the increase of egg production of goose.

In addition, estrogen was also essential to stimulate granulosa cell proliferation and facilitate the function of FSH and LH in follicles (Richards, 1980). Previous researches showed that $\alpha$-tocopherol was positively associated with E2 and free E2 in healthy women (Mumford, Browne, Schliep, Schmelzer, Plowden, Michels, Sjaarda, Zarek, Perkins, Messer, 2015). In our findings, the concentration of E2 was increased at doses of 20-160 mg/kg of vitamin E supplementation. In accordance with the function of vitamin $E$ in organisms, it was conjectured that vitamin E may affect the concentration of E2 in three aspects. Firstly, vitamin E protected the structural integrity of theca cells, a kind of cell mainly for the synthesis and secretion of estradiol, through scavenging the free radicals to oxidize polyunsaturated fatty acids and lipoproteins on the membrane. For the second aspect, as a main ingredient for the synthesis of estradiol, the transport of cholesterol is consistent with vitamin $\mathrm{E}$ transportation in intestinal epithelial cells, which improves the synthesis of estradiol. Furthermore, granular cell, an essential role in follicle, functioned as regulating the development of follicle and promoting the synthesis of steroid hormones (Onagbesan et al. , 2009). As previous findings reported that the proliferation of granular and theca cells were regulated by FSH and LH (Drummond, 2006). This means that serum E2 concentration may indirectly regulate by the concentration of FSH and $\mathrm{LH}$ as well.

$P R L$, secreting from lactotroph cell of the anterior pituitary, was confirmed to induce broodiness in birds (El Halawani et al., 1980). As described previously, PRL expression pattern in contrast with E2 increased in broodiness and decreased in the breeding period (Chen et al., 2005). The synthesis and secretion of prolactin were regulated by Pou1f1 transcription factor, dopamine, estradiol and other factors (Scully et al., 1997, Denef, 2008, Numan \& Woodside, 2010). High concentration PRL secretion in broodiness suppressed the release of $\mathrm{LH}, \mathrm{E} 2$ and progesterone in ovary and reduced the number of normal follicles (Sharp et al., 1988), which may suppress a series of reproductive activities. In this study, the pattern of serum PRL concentration was distinctive, which increased at low vitamin E supplementation (10 and $20 \mathrm{mg} / \mathrm{kg}$ ) and reduced at intermediate and high level (>20 mg/ $\mathrm{kg}$ ). This result may be explained as the changes of E2 concentration caused by the influence of vitamin E supplementation affected the expression of PRL gene (Lieberman et al., 1981). Otherwise, the acute changes in PRL output were most likely to be a result of altered inhibition by hypothalamic dopamine, since it was tonic inhibition by this factor which primarily regulates PRL secretion (Lieberman, Maurer, Claude, Wiklund, Wertz, Gorski, 1981, Freeman et al., 2000). Whilst vitamin E confirmed to have an effect on the monoamine metabolism in rat brain and vitamin E deficiency may reduce the dopamine levels in the brain stem(Adachi et al., 1999). Thence, the concentration of PRL increased at low levels vitamin $E$ and may cause abrupt increases of estradiol. As for the decrease of PRL content when vitamin E supplementation exceeded $20 \mathrm{mg} / \mathrm{kg}$, that could be related to the increase of dopamine content in the brain which inhibited the synthesis and secretion of PRL.

In the current study, we confirmed that the supplementation of dietary vitamin E could improve the concentration of reproductive hormones in serum and the expression of reproductive hormone receptor genes in the ovary. Furthermore, it was observed that the appropriate level of vitamin E for reproductive hormone concentration tested in this study was $80 \mathrm{mg} /$ $\mathrm{kg}$, which was consistent with the result of Lin's finding that $80 \mathrm{mg} / \mathrm{kg}$ vitamin $\mathrm{E}$ was the most appropriate content for egg production, hatchability and fertility (Lin et al., 2004). Plasma gonadotropin concentration was supposed to present strong correlations with gonadotropin genes in pituitary and gonadotropin receptor genes in the ovary (Brooks et al., 1992). It was demonstrated that the effect of FSH on the ovary was mainly exerted by binding to the specific receptor of the granulosa cell membrane, FSHR (Lu et al., 2009). In the current study, we found that the expression patterns of reproductive hormone receptor genes (FSHR, ESR1, LHR and PRLR) in the ovary were similar to the reproductive hormone expression patterns. 
Additionally, PRLR mRNA expressed relatively lower in the ovary compared with other hormones. Therefore, the release of PRL in the pituitary could be inhibited by a higher concentration of E2. Interestingly, all hormones, but PRL, were observed to show a decreasing trend above $80 \mathrm{mg} / \mathrm{kg}$ vitamin $\mathrm{E}$ supplementation. This result could be explained as the negative feedback existing in hypothalamic-pituitary-gonadalaxis. Once the concentration of reproductive hormones in serum exceeds the normal level, a regulation of negative feedback in the hypothalamic- pituitary-gonadal axis would inhibit the origin of reproductive hormones. Moreover, high dose of vitamin E supplementation may reduce the cholesterol content for the synthesis of estradiol, which could further reduce the synthesis and release $\mathrm{FSH}$ and $\mathrm{LH}$ in the pituitary.

Dicer, as a ribonuclease, was found to be critical for reproduction. It was reported that suppressing the expression of Dicer could reduce the maturation rate of oocyte and suppression of gonadotropin synthesis (Wang et al., 2015). As shown in the results (Figure $2,3)$, the expression of FSHR, ESR 1 and $L H R$ increased with the increasing expression of Dicer at $40-80 \mathrm{mg} / \mathrm{kg}$ dose of vitamin E supplementation in the ovary. Yu's view rests on the result that joint comparisons revealed 23 upregulated and 21 downregulated miRNAs in laying stage and confirmed miRNAs involved in follicular atresia directly (Yu et al., 2016). Since miRNAs participate in follicular atresia and development, the expression of Dicer in the different stage of follicles should be detected. The relative mRNA expression of Dicer in the ovary, SWF, LWF and SYF were detected in this study. Compared with other tissues, lower mRNA expression of Dicer was observed in LWF with no vitamin E supplementation. This result was supposed to be associated with the different physiological changes, mainly protein and steroid accumulation, occurred in the ovary and follicles in different stages. As described in Guan's study, the main changes presented in pre-hierarchical follicle development were yolk accumulation, granulosa cell and membrane cell proliferation and differentiation(Guan et al., 2015). However, the specific mechanism of Dicer expressed a decrease in LWF and needs to be clarified further. In this study, the relative mRNA expression of Dicer in the ovary increased at the dose of $40 \mathrm{mg} / \mathrm{kg}$ of vitamin E, whereas in SWF, LWF and SYF, Dicer mRNA expression-increased at the dose of $80 \mathrm{mg} / \mathrm{kg}$ of vitamin $\mathrm{E}$ supplementation. It was speculated that the differential expression of Dicer in the ovary and follicles affected by different doses of dietary vitamin
E supplementation may be due to vitamin E sensitivity and protein expression diversity of ovary and follicles in different developmental stages.

\section{ACKNOWLEDGEMENTS}

This work was funded by the National Natural Science Foundation of China (Nos. 31172181 and 31660663) and the National Waterfowl Industrial Technology System (No. CARS-43-4 and 2016YFD0500510). We are grateful to the animals provided by Xingguo Grey Goose Research Base and research facility provided by the Institute of Animal Genetics and Breeding, Sichuan Agricultural University and all the volunteers who participatedin the study.

\section{CONFLICT OF INTEREST}

The authors declare that they have no competing interests.

\section{REFERENCES}

Abedi P, Tabatabaei Vakili S, Mamouei M, Aghaei a. Effect of different levels of dietary vitamin $\mathrm{E}$ on reproductive and productive performances in Japanese quails (Coturnix coturnix japonica). Veterinary Research Forum 2017;8(4): 353-359.

Adachi K, Izumi M, Mitsuma T. Effect of vitamin E deficiency on rat brain monoamine metabolism. Neurochemical Research 1999;24(10):13071311.

Biswas A, Mohan J, Sastry KV. Effect of higher dietary vitamin E concentrations on physical and biochemical characteristics of semen in Kadaknath cockerels. British Poultry Science 2009;50(6):733-738.

Biswas A, Mohan J, Sastry KVH.. Effect of vitamin E on production performance and egg quality traits in indian native kadaknath hen Asian-Australasian Journal of Animal Sciences 2010;23(3): 396-400.

Brooks J, Crow WJ, Mcneilly JR, Mcneilly AS. Relationship between gonadotrophin subunit gene expression, gonadotrophin-releasing hormone receptor content and pituitary and plasma gonadotrophin concentrations during the rebound release of $\mathrm{FSH}$ after treatment of ewes with bovine follicular fluid during. Journal of Molecular Endocrinology 1992;8(2):109-118.

Chen X, Zhang M, Yuan S. Study on the reproduction hormone level of female wanxi white geese. China Poultry 2005;(Supl 1).

Denef $C$. Paracrinicity: the story of 30 years of cellular pituitary crosstalk Journal of Neuroendocrinolpgy 2008;20(1):1-70.

Drummond AE. The role of steroids in follicular growth. Reproductive Biology Endocrinology 2006;4:16

El Halawani ME, Burke WH, Dennison PT. Effect of nest-deprivation on serum prolactin level in nesting female turkeys. Biology Reproduction 1980; 23(1):118-123.

Freeman ME, Kanyicska B, Lerant A, Nagy G. Prolactin: structure, function, and regulation of secretion. Physiological Review 2000;80(4):15231631. 
Guan S, Guo L, Zhang T, Zhu B, Wang X, Zhang C. Effects of gonadotropin on Fas and/or FasL expression and proliferation in rat ovary. Theriogenology 2015;83(1):21-29.

Hardy K, Fenwick M, Mora J, Laird M, Thomson K, Franks S. Onset and heterogeneity of responsiveness to fsh in mouse preantral follicles in culture. Endocrinology 2017;158(1): 134-147.

Hooda S, PK Tyagi PK, Mohan J, Mandal AB, Elangovan AV, Pramod T. Effects of supplemental vitamin $E$ in diet of Japanese quail on male reproduction, fertility and hatchability. British Poultry Science 2007;48(1):104-110

Kurzynska-Kokorniak A, Koralewska N, Pokornowska M, Urbanowicz A, Tworak A, Mickiewicz A, et al. The many faces of Dicer: the complexity of the mechanisms regulating Dicer gene expression and enzyme activities. Nucleic Acids Research 2015;43(9):4365-4380.

Lieberman ME, Maurer RA, Claude P, Wiklund J, Wertz N, Gorski J. Regulation of pituitary growth and prolactin gene expression by estrogen. Advances and Experimental Medicine Biology 1981;138:151163.

Lin JX, Jia YD, Zhang CQ. Effect of epidermal growth factor on folliclestimulating hormone-induced proliferation of granulosa cells from chicken prehierarchical follicles. Journal of Science da Universidade de Zhejiang B 2011;12(11):875-883.

Lin YF, Chang SJ, Hsu AL. Effects of supplemental vitamin E during the laying period on the reproductive performance of Taiwan native chickens. British Poultry Science 20014;45(6):807-814.

Liu K, Ge S, Luo H, Yue D, Yan L. Effects of dietary vitamin E on muscle vitamin $\mathrm{E}$ and fatty acid content in Aohan fine-wool sheep. Journal Animal Science and Biotechnology 2013;4(1): 21.

Liu M, Gan S, Song M, Zeming BU, Lisui SU, Zhang G, et al. Effects of dietary vitamin Elevel on growth performance, antioxidant function and PPARs expression of guangxi sanhuang chicken. China Poultry 2017;39(17).

Lu C, Yang W, Chen M, Liu T, Yang J, Tan P, et al. Inhibin A inhibits folliclestimulating hormone (FSH) action by suppressing its receptor expression in cultured rat granulosa cells. Molecular Cellular Endocrinology 2009;298(1-2):48-56.

Makpol S, Zainuddin A, Rahim NA, Yusof YA, Ngah WZ. Alpha-tocopherol modulates hydrogen peroxide-induced DNA damage and telomere shortening of human skin fibroblasts derived from differently aged individuals. Planta Medica 2010;76(9):869-875.

Mumford SL, Browne RW, Schliep KC, Schmelzer JC, Plowden TC, Michels $K A$, et al. Serum antioxidants are associated with serum reproductive hormones and ovulation among healthy women. Journal of Nutrition 2015;146(1):98.

Numan M, Woodside B. Maternity: neural mechanisms, motivational processes, and physiological adaptations. Behavioral Neuroscience 2010;124(6):715-741.
Onagbesan $\mathrm{O}$, Bruggeman $\mathrm{V}$, Decuypere $\mathrm{E}$. Intra-ovarian growth factors regulating ovarian function in avian species: a review. Animal Reproduction Science 2009;111(2-4):121-140.

Otomaru K, Saito S, Endo K, Kohiruimaki M, Ohtsuka H. Effect of supplemental vitamin $\mathrm{E}$ on the peripheral blood leukocyte population in Japanese black calves. Journal of Veterinary Medical Science 2015:77(8):985-988.

Otsuka M, Zheng M, Hayashi M, Lee JD, Yoshino O, Lin S, et al. Impaired microRNA processing causes corpus luteum insufficiency and infertility in mice. Journal of Clinical Investigation 2008;118(5):1944-1954.

Richards JS. Maturation of ovarian follicles: actions and interactions of pituitary and ovarian hormones on follicular cell differentiation. Physiological Reviews 1980;60(1):51-89.

Scully KM, Gleiberman AS, Lindzey J, Lubahn B, Korach KS, Rosenfeld MG. Role of estrogen receptor-alpha in the anterior pituitary gland. Molecular Endocrinology 1997;11(6):674-681.

Sharp PJ, Macnamee MC, Sterling RJ, Lea RW, Pedersen HC. Relationships between prolactin, $\mathrm{LH}$ and broody behaviour in bantam hens. Journal of Endocrinology 1998;118(2):279.

Singh B, Singh H, Singh CV, Singh B. Genetic parameters of growth, egg production and egg quality traits in White Leghorn. Journal of Poultry Science 2000;35:1-13.

Song MS, Rossi JJ. Molecular mechanisms of Dicer: endonuclease and enzymatic activity. Biochemical Journal 2017;474(10):1603-1618.

Tongsiri S, Jeyaruban MG, Van Der Werf JH. Genetic parameters for egg production traits in purebred and hybrid chicken in a tropical environment. British Poultry Science 2015;56(6):613-620.

Veeramani P, ChurchilRR, Kutty KN. Estimates of heritability and correlations of economic traits in two strains of White Leghorn. International Journal of Veterinary Science 2012;1(2):45-48.

Wang H, Graham I, Hastings R, Gunewardena S, Brinkmeier ML, Conn PM, et al.. Gonadotrope-specific deletion of Dicer results in severely suppressed gonadotropins and fertility defects. Journal of Biological Chemistry 2015;290(5):2699-2714

Xie JF, Liu LX, Yan-Ping WU, Zhou QY, Xie MG, Wei QP, et al. Preliminary study on control technology of seasonal reproduction of grey geese in Xingguo. Acta Agriculturae Jiangxi 2011;1.

Young LG, Lumsden JH, Lun A, Claxton J, Edmeades DE. Infleuce of dietary levels of vitamin $\mathrm{E}$ and selenium on tissue and blood parameters in pigs. Canadian Journal of Comparative Medice 1976;40(1):92-97.

Yu J, He K, Ren T, Lou J, Zhao A. High-throughput sequencing reveals differential expression of miRNAs in prehierarchal follicles of laying and brooding geese. Physiological Genomics 2016;48(7):455-463. 
